This paper has been accepted for publication in Journal of Industrial Relations and the final (edited, revised and typeset) version appears in Journal of Industrial Relations, Vol. 57, No. 3, June 2015, by SAGE Publications Ltd, All rights reserved. DOI: 10.1177/0022185615571981 (C) Australian Labour and Employment Relations Association (ALERA). For more information, please visit: www.sagepublications.com

\title{
The Australian Labour Market in 2014: Still Ill?
}

\author{
Joshua Healy \\ National Institute of Labour Studies \\ Flinders University \\ GPO Box 2100 \\ Adelaide SA 5001 \\ Australia
}




\begin{abstract}
The Australian labour market remained in a subdued state during 2014. Participation and employment rates fell, while unemployment and underemployment rates rose. Of the limited employment growth that did occur, most was in the part-time workforce and concentrated on prime-aged and older workers. After exhibiting serious weakness in 2013, the youth labour market deteriorated further in 2014. A rise in job vacancies was a sign of possible improvement, but employers' confidence has not yet recovered to nearly the extent necessary to end the labour market slowdown of recent years.
\end{abstract}

\title{
Keywords
}

Australian economy, minimum wage, participation, pay, productivity, unemployment 


\section{Introduction}

This article looks back at the state of the Australian labour market during 2014. The discussion covers changes in labour force participation, workforce composition, and earnings. As well as summarising the specific Australian trends, the article attempts to place these developments within the wider international context, through comparisons with data for the 34 member countries of the Organisation for Economic Cooperation and Development (OECD).

The Australian labour market remained in a subdued state during 2014, after showing signs of weakness for several years. Labour force participation and employment rates declined, while unemployment, long-term unemployment and underemployment rates increased. Of the limited employment growth that occurred, most has been in the parttime workforce, and yet prime-aged and older workers, rather than youths, have been the main beneficiaries of this improvement. The labour market for young Australians deteriorated further in 2014 from its already troubled state in 2013 (Healy, 2014). One possibly encouraging development was a lift in the number of job vacancies, but the extent of this improvement was not enough to offset recent declines or to assist large numbers of the unemployed. Overall labour demand remains weak and there is a looming prospect of continuing weakness for much of 2015. These and other developments are discussed at greater length in the article.

\section{Macroeconomic overview}

Changes in aggregate economic performance provide a useful context for interpreting labour market outcomes. Table 1 shows the key Australian macroeconomic indicators for the 2013-14 financial year (to June 2014) and comparable figures for the OECD. The Australian economy recorded its $23^{\text {rd }}$ consecutive year of growth in 2014, with Gross Domestic Product increasing (in real terms) by 2.5\%. For the past 10 years, the 
economy has expanded by an average of 2.8\% per year. By this measure, 2012 was an exceptionally strong year, while 2013 and 2014 were both marginally below average.

$<$ Table 1 here $>$

Australia has maintained a consistently favourable performance when compared with the rest of the developed world. Many OECD countries remain mired in the aftermath of a severe recession and austerity policies that continue to undermine confidence and economic growth (and, in some cases, risk triggering a slide back into recession). The Australian GDP and GDP per hour worked figures have easily outstripped the OECD average for the past three years. This is especially true of GDP per hour worked (the measure of labour productivity), which was revised upwards significantly for 2012 and 2013 in the most recent Australian National Accounts. ${ }^{1}$ In terms of GDP per capita, however, which captures changes in average population living standards, Australia has been on par with (or slightly below) the OECD average for the past two years. Thus, while the Australian economy is currently more productive than others (relative to its size), this rising prosperity has been accompanied by stronger population growth, leading to smaller gains in the rate of output growth per head of population.

\section{Labour market conditions}

Table 2 shows key performance statistics for the Australian labour market as a whole in the past three years, and compares these to the equivalent figures for the OECD. The focus is on the working-age population (15-64 year olds). The Australian picture for 2014 is troubling; all of the indicators have moved in an unfavourable direction. The participation rate (the proportion of the population in work or seeking work) fell, as did the total employment and full-time employment rates. Perhaps most concerning 
is that the unemployment rate climbed, even in the context of declining participation. It is not unusual during recoveries for the unemployment rate to increase temporarily, because more people are entering the labour market and the process of matching these new entrants to the available jobs takes time. In Australia during 2014, however, the opposite has occurred: people have withdrawn from the labour force, but those that remain have not enjoyed better prospects. Jobs have become scarcer even though the competition for them has eased, suggesting continuing and widespread weakness in labour demand.

\section{$<$ Table 2 here $>$}

Unfortunately, Table 2 shows that 2014 was not an isolated 'bad year' for the labour market, but the second consecutive year of worsening conditions. The unemployment rate rose by 0.4 percentage points in both 2013 and 2014. This represents a significant cumulative increase, and suggests that the current labour market slowdown may last for some time yet. By other measures, the rate of decline actually accelerated in 2014. The overall employment rate (i.e. for both sexes) fell by 0.5 percentage points in 2014 (from $72.1 \%$ to $71.6 \%$ ) compared with a 0.3 percentage point fall in 2013 . The fulltime employment rate fell even more sharply, by 0.6 percentage points (from $51.1 \%$ to 50.5\%). These are not promising signs that the labour market has 'turned a corner' to begin a period of sustained improvement.

There are also gendered patterns to the results in Table 2. The general picture is of a more serious malaise in the labour market for males than for females, but problems are apparent for both sexes. Employment rates have fallen and unemployment rates have risen consistently in the past two years, for both sexes. The unemployment rate is now slightly higher for females than for males, but the male rate has increased more 
rapidly in the past two years. The single largest change in the Australian figures is the steep recent decline in the male full-time employment rate. This rate fell by 0.9 percentage points in 2014 and has fallen by 1.5 percentage points over the past two years. Again, this represents a significant adverse change in a crucial part of the labour market. The vast majority of male employment in Australia is full-time (84\% in 2014) and males hold $64 \%$ of all the full-time jobs. So a decline in male full-time employment is not only an individual labour market problem; it also hints at further social problems for families that depend on stable full-time earnings. The loss in male full-time employment has also been accompanied by female losses, but these are smaller in magnitude. An important gender difference in Table 2 is that the female labour force participation rate has been stable or even increasing slightly, unlike the receding male participation rate. As noted previously and elsewhere (Gong, 2011; Healy, 2014), this may be partly an 'added-worker effect': females stepping up their participation in response to their male partners’ diminished prospects.

How do these Australian developments compare with broader outcomes in the OECD countries? In the main, they are more favourable: the Australian unemployment rate has been 2-3 percentage points lower than the OECD's for each of the past three years. On the other hand, the direction of change for the OECD is more positive than for Australia. The unemployment rate is stable or falling for the OECD, and employment rates are generally rising. The 0.8 percentage point increase in the OECD male full-time employment rate is a stark contrast to the ailing male full-time employment situation in Australia. Overall, while the Australian labour market is undoubtedly in better health than the aggregate labour market of the OECD, recent developments have narrowed the gap to Australia's detriment. 
The main story in the recent Australian labour market is one of growing 'slack' - an increase in the supply of available workers relative to the demand. In Table 3, we look in closer detail at the extent of change in labour force underutilisation in Australia and the OECD. Unemployment, long-term unemployment and underemployment rates are shown for the past three years for males and females, and separately for youths (15-24 year olds), whose prospects have been especially affected by the downturn in demand. 'Long-term' unemployment is a continuous spell of one year or more and is expressed as a percentage of total unemployment. 'Underemployment' refers (in Australia) to those who want and are ready to work additional hours, or (in the OECD) to part-time workers who want full-time work. ${ }^{2}$ Both underemployment rates are expressed as percentages of the labour force.

$<$ Table 3 here $>$

The overall impression from Table 3 is that Australia faces a deepening labour force underutilisation problem. There is more unemployment, more of it is long-term, and more of those who have found work want additional hours. Both sexes have shared in these deepening problems, but not evenly. The unemployment and underemployment rates increased more rapidly for females in 2014, whereas the bulk of the increase in long-term unemployment has occurred among males. It is useful to contextualise these differences by estimating the potential 'volume' of additional working hours that each form of underutilisation represents for each sex. The volume of total hours sought by the unemployed is greater than that sought by the underemployed (by around 65\%) and there are more unemployed males than females (by around 15\%). It follows that fulfilling the working-time preferences of all the current unemployed and underemployed would result in a larger addition to hours worked by males than by 
females. Specifically, males would contribute $55 \%$ of the increase in hours worked. Of course, these calculations say nothing about the relative difficulty that would be involved, in practice, in meeting the preferences of the various underutilised groups. Employers may be more willing to accommodate the preferences of their existing underemployed workers (e.g., through more flexible work arrangements) than to hire from among the unemployed. Falling underemployment rates may thus be an early indicator of labour market improvement. While the present state of underutilisation persists, however, the skills and re-employment prospects of the growing numbers of long-term unemployed are dwindling. The lesson of previous downturns is that some, especially less-educated males, will become disheartened and leave the labour force permanently (Gregory, 2012).

Table 3 also highlights a further deterioration in the Australian youth labour market in 2014. The youth unemployment rate was already twice that of the whole labour force, and has risen steeply again this year. The long-term unemployment rate for youths has also shot up by several percentage points. To put these figures into perspective, 15-24 year old Australians accounted for $30 \%$ of the increase in total unemployment during 2014, and 41\% of the increase in long-term unemployment. The effects of the current labour market downturn are thus felt strongly by young and inexperienced jobseekers. Another difficult year has driven Australia's youth unemployment rate rapidly closer to the perilously high level already present for the OECD as a whole (also in Table 3). Against a backdrop of increasing unemployment and forecasts of continuing problems during 2015 (RBA, 2014), the Australian Government made or proposed a number of important changes to labour market ‘activation’ policies for jobseekers. These policies seek to increase work participation and engagement through incentives for job search 
and job retention, and disincentives for prolonged welfare dependence. Some of the changes announced in 2014 were broadly focused, such as directing new jobseekers to different 'streams' of employment support according to assessed work readiness, and tightening ‘mutual obligation’ requirements for receiving income support (Australian Government, 2014b). Other proposals were targeted specifically at young jobseekers, among which unemployment rates are acutely high (Table 3). In the 2014/15 Budget, the Government announced that jobseekers under 30 years of age and without prior work experience would serve a six-month waiting period for the Newstart Allowance. The proposal failed to win the necessary support in the Parliament and remains stalled without having taken effect at the time of writing (Australian Government, 2014a). The legislative impasse that some of the Government's policies have met, along with the prospects of a continuing slump in the labour market during 2015, mean that the unemployed will remain a focus of political and economic debates in the year ahead. The Government will face further pressure to jettison or dilute those parts of its policy agenda that are seen as punitive to jobseekers and unlikely to assist job creation at a time of weak aggregate labour demand (The Conversation, 2014a).

One possibly encouraging sign in the recent Australian labour market is an increase in the total number of job vacancies, and the proportion of these vacancies being filled. The direction of change in most of the vacancy indicators (Table 4) suggests some improvement in employers' propensity to hire new workers during 2014. The ABS measure of total vacancies rose by 4-5\%, the Department of Employment's Internet Vacancy Index (IVI) rose by 11-13\%, and the proportion of vacancies filled rose from $70 \%$ to $73 \%$ overall (and from $76 \%$ to $81 \%$ for professional occupations).

$<$ Table 4 here $>$ 
While these developments may be indicative of some labour market strengthening, their significance should not be overplayed. As seen in Table 4, the recent increases in vacancy volumes have only partially reversed the decreases of previous years, and the numbers are not nearly at the levels that would be needed to bring many of the current unemployed back to work. Second, firms may be looking for attributes in new recruits that many current jobseekers do not possess. It is well known that recent decades have seen employment opportunities change in ways that advantage highly-skilled workers (see Wilkins and Wooden, 2014, for a recent Australian review). It is also recognised that in slack labour market conditions, when labour is abundant, employers become more selective in their hiring; they look for attributes that would not be readily found at other times (Richardson, 2007). Both effects suggest that new job vacancies may be taken by better-placed applicants, including workers moving between jobs, with fewer opportunities being created for inexperienced and disadvantaged jobseekers.

\section{Employment changes in detail}

We next examine changes in the composition of the Australian employee workforce. Table 5 shows estimates of employment change for the past three years, including the differences by sex, age group, working hours, and State/Territory. Changes are shown in terms of both numbers employed ('headcount') and hours worked, to adjust for Australia’s high part-time employment rate.

$<$ Table 5 here $>$

After slowing for the two previous years, the rate of growth in the headcount measure of total employment fell further in 2014 (from 1.8\% to 1.2\%) and the growth in total hours worked was weaker still (0.6\%). This suggests that much of the year's limited employment growth was due to part-time and short-hours jobs; this is borne out by 
the other figures in Table 5. In sum: the shorter the working week, the stronger the employment growth during 2014. The Australian labour market added many new part-time jobs with less than 35 hours of work, but barely any new full-time jobs with 35 or more hours of work. The total number of jobs (and hours worked) fell sharply in the 50 hours or more range. The net effect of these changes was a reduction in the length of the average working week from 33.9 to 33.7 hours.

Part-time employment growth is normally beneficial to females and youths, as many of these workers have and prefer part-time work. The stronger employment result for females than for males in Table 5 is consistent with the overall shift from full-time to part-time employment that occurred during 2014. The more disappointing feature of Table 5 is that young people did not benefit to nearly the same extent from this shift. While there was some increase in youth part-time employment, this was outweighed by a sharp reduction in youth full-time employment. The headcount employment measure for $15-24$ year olds fell by $-1.2 \%$ in 2014 , and the hours worked measure fell by $-3.0 \%$. In both cases, these were the largest reductions in three years and the third consecutive years of decline. The other age groups have not fared nearly as badly, with total employment expanding modestly for prime-age workers (1.3\%), and more rapidly for older workers (3.0\%), in 2014. Recent employment changes have thus played out quite differently according to age, with young workers bearing the brunt of the adjustment. One likely explanation for this is 'bumping-down': more-experienced workers are forced into lower-level positions by widespread reductions in job security and hiring, displacing the less-experienced workers that would normally take these positions. 
Other evidence underscores the depth of the current difficulties in the Australian youth labour market. Graduate Careers Australia (GCA) tracks the employment and wage outcomes of recent Australian university graduates four months after finishing their studies. GCA's latest Australian Graduate Survey (AGS) indicates that fewer graduates are in full-time employment, and more of them are not working, than has been the case for many years. Of those who completed a Bachelor's Degree in 2013 and who were available for full-time work four months after graduation, 68.1\% were employed full-time, 20.3\% were employed part-time or casual while looking for fulltime work, and $11.6 \%$ were not employed while looking for full-time work (GCA, 2014: 4). The proportion of graduates employed full-time (68.1\%) has not been lower at any time in the past 24 years. The proportion currently employed part-time or casual while looking for full-time work (20.3\%) has doubled since 2008, and is now well above the peak levels seen in previous downturns (GCA, 2014: 5). It is not only the graduate labour market that has been badly affected by the current slowdown. For the third consecutive year, the number of 15-24 year olds commencing trades apprenticeships has fallen; to 56,800 for the year ending June 2014 (NCVER, 2014: Table 11). This slowing in the uptake of apprenticeships can be expected to flow through into lower youth employment in trades occupations over the coming months and years (see Karmel and Oliver, 2011). Graduate jobs and trades apprenticeships are thus underperforming in their usual role of providing entry points into the skilled workforce for Australian youth. These particular problems are both a symptom and a cause of the overall weakness in demand that has afflicted the Australian labour market in recent years, and that now threatens to extend into 2015.

The bottom panel of Table 5 shows marked differences in labour market outcomes for the States and Territories during 2014. On both employment measures, the Northern 
Territory had the strongest labour market and South Australia the weakest. Employment growth outpaced the national average in the Northern Territory, Queensland and Western Australia, and (on an hours-worked basis only) in Tasmania. The larger labour markets of the most-populous States performed less impressively. Employment expanded modestly in New South Wales, but contracted on an hoursworked basis in Victoria (by -0.3\%). The Victorian labour market has underperformed relative to the rest of Australia in each of the past three years, as a combination of manufacturing job losses and a service-sector downturn has weakened the State's economy.

Further evidence is available (but not shown in Table 5) about employment changes by industry. The largest employment growth rates in 2014 were in the Rental, Hiring and Real Estate Services (9.7\%), Other Services (9.3\%), and Agriculture, Forestry and Fishing (6.1\%) industries. These were also the strongest-performing industries in terms of the growth in hours worked. However, none of these industries is particularly large in size. Hence, other industries accounted for greater shares of total employment growth during 2014. The largest increases were in Health Care and Social Assistance and Retail Trade; these two industries together accounted for $40 \%$ of the new jobs created in 2014 (and 38\% of the increase in total hours worked).

Over the past three years, Mining and Education and Training have been other strong performers, alongside Other Services and Health Care and Social Assistance. Mining employment has increased by $25 \%$ in the past three years (despite a small reduction in 2014), consistent with the ongoing boom in investment and production. Employment in Education and Training has expanded at a steady 2-3\% since 2011. At the other end of the scale, employment has contracted in the past three years in Information Media 
and Telecommunications (-3.4\%), Administrative and Support Services (-1.8\%), and Manufacturing (-1.7\%). The share of all Australian employment in Manufacturing has been shrinking for many years, but the industry’s fortunes in 2014 were battered by a continuing high Australian dollar and the announcement that Toyota (like Holden and Ford before it) would close its Australian vehicle production plants in the next three years (The Conversation, 2014b). ${ }^{3}$ The employment losses in IT and Administration reflect a combination of cyclical and structural factors. Some jobs growth is likely as confidence returns to the industries that use technical and administrative support services. But there are also larger changes underway, including the restructuring of broadcast and print media and the continued 'offshoring' of IT and administrative jobs to lower-cost developing countries, such as India.

\section{Earnings inequality and the minimum wage}

This final section considers recent changes in employee remuneration, including the extent of earnings inequality and the level of the National Minimum Wage (NMW). The growing disparities in employment documented earlier (and elsewhere) have also been playing out in the Australian wage structure. Figure 1 provides a broad summary of earnings growth trends for the past decade. The information is for full-time weekly earnings of male and female employees in their main job. ${ }^{4}$

Figure 1 compares mean and median weekly earnings growth from the base year of 2004. A difference between these provides a simple indication of changes in earnings inequality. ${ }^{5}$ Over the period shown, two main earnings trends emerged in the full-time workforce. First, male earnings grew more quickly than female earnings, on both measures. Second, mean earnings growth exceeded median earnings growth, for both sexes (a difference of 7 percentage points in both cases). Earnings inequality has thus 
increased in the past 10 years, and gender differences in outcomes have been contributing to that change.

The increase in earnings inequality can also be depicted in other ways. Wilkins and Wooden (2014) compute the changes in real (inflation-adjusted) earnings for full-time employees at each percentile of the distribution between 1994-95 and 2011-12. Their analysis shows a strong positive relationship between initial earnings and the pace of real earnings growth in this period. There has been improvement at all percentiles, but the largest gains have been for those who were already better-paid. Employees in the top-half of the earnings distribution have gained ground on those in the middle, who in turn have pulled away further from those in the bottom-half of the distribution. The earnings of the lowest-paid workers have improved, but not to nearly the same degree as for the average worker. Earnings inequality has grown, as higher-paid employees have taken home a steadily larger share of the gains from rising national productivity.

$<$ Figure 1 here $>$

Many of Australia’s lowest-paid workers receive award-based minimum wage rates, which are reviewed and adjusted annually by the Fair Work Commission (FWC). The Expert Panel of the FWC must take into account various economic and social factors when making these decisions, including 'relative living standards and the needs of the low paid' (s.284 of the Fair Work Act 2009). The Panel has been well informed about the extent of earnings inequality in the Australian workforce and its consequences for the relative living standards of award-reliant workers. The Panel has also increasingly recognised the limitations of dollar-value minimum wage adjustments, which do little for award-reliant workers above the National Minimum Wage (NMW) (Healy, 2011). Since 2011, the Panel has resumed the practice of making minimum wage increases in 
percentage terms, thereby helping to maintain the real values of the higher award rates as well as the NMW.

The FWC increased the nominal value of all award minimum wages by $3.0 \%$ in 2014 , including the NMW. The Expert Panel saw fit to make a larger increase than the $2.6 \%$ granted in 2013. In its decision, the Expert Panel referred to forecasts of strengthening employment growth in 2014-15 and noted that: 'In aggregate, there are no signs of cost pressures arising from the labour market' (FWC, 2014: 11). Faced with evidence of rising earnings inequality similar to that shown in Figure 1, the Panel said: 'No party disputed the fact that the distribution of earnings has become more unequal in Australia over recent decades and the Panel acknowledges that annual wage review decisions have a role to play in ameliorating inequality' (FWC, 2014: 12). The 3.0\% increase would deliver 'a modest improvement in the real value of ... minimum wages' and would help to ensure that award-reliant workers benefited from the general improvement in Australian living standards (FWC, 2014: 13).

\section{$<$ Table 6 here $>$}

Table 6 looks at the practical effects of the FWC decision, by comparing it to various wage and earnings benchmarks for the past four years. The 2014 minimum wage rise was identical to the annual increase in the Consumer Price Index to June 2014, so the real value of award rates did not decline (but did not increase either, despite what the FWC Panel intended). For the first time in four years, however, minimum wages rose faster than all other measures of wage and earnings growth. As with the labour market more generally, wage growth was subdued in 2014; this is seen most clearly from the Wage Price Index (WPI) data in Table 6, which shows slowing growth year on year in the broadest (All industries) measure. ${ }^{6}$ The 3.0\% FWC increase therefore improved 
the relative incomes of the lowest-paid for the first time in several years. The Panel's goal of ensuring that award-reliant workers obtain a more equitable share of the gains from rising national productivity was achieved in 2014. The 3.0\% increase was also enough to (temporarily) arrest the decline in the value of the NMW as a proportion of average weekly earnings (42.7\% in 2014).

\section{Conclusion}

The Australian labour market has entered a difficult phase. Ongoing demographic and structural changes, the high Australian dollar, and a cyclical downturn in output and confidence, have seen the labour market deteriorating on several fronts. Participation and employment rates fell in 2014, while unemployment and underemployment rates rose. The encouragement offered by an increase in job vacancies was tempered by the continued rise in joblessness, particularly among youths in long-term unemployment. The general labour market slowdown has also led to weaker wage growth; one upside of which is a modest improvement in the relative value of award minimum wages due to the $3.0 \%$ increase of the FWC. A risk is that the economic forecasts on which this decision was (partly) based will prove to be overly sanguine in the coming year. This prospect looks increasingly likely in light of the latest Australian National Accounts, which show a further slowing of GDP growth in the third quarter of 2014. The 'silver lining' for parts of the economy is the further fall in the value of the Australian dollar that followed this announcement (Janda, 2014). 


\section{References}

Australian Bureau of Statistics (ABS) (2005) Employee Earnings, Benefits and Trade Union Membership, Australia, August 2004. Cat. no. 6310.0. Canberra: ABS.

Australian Bureau of Statistics (ABS) (2006) Employee Earnings, Benefits and Trade Union Membership, Australia, August 2005. Cat. no. 6310.0. Canberra: ABS.

Australian Bureau of Statistics (ABS) (2007) Employee Earnings, Benefits and Trade Union Membership, Australia, August 2006. Cat. no. 6310.0. Canberra: ABS.

Australian Bureau of Statistics (ABS) (2008) Employee Earnings, Benefits and Trade Union Membership, Australia, August 2007. Cat. no. 6310.0. Canberra: ABS.

Australian Bureau of Statistics (ABS) (2009) Employee Earnings, Benefits and Trade Union Membership, Australia, August 2008. Cat. no. 6310.0. Canberra: ABS.

Australian Bureau of Statistics (ABS) (2010) Employee Earnings, Benefits and Trade Union Membership, Australia, August 2009. Cat. no. 6310.0. Canberra: ABS.

Australian Bureau of Statistics (ABS) (2011) Employee Earnings, Benefits and Trade Union Membership, Australia, August 2010. Cat. no. 6310.0. Canberra: ABS.

Australian Bureau of Statistics (ABS) (2012) Employee Earnings, Benefits and Trade Union Membership, Australia, August 2011. Cat. no. 6310.0. Canberra: ABS.

Australian Bureau of Statistics (ABS) (2013) Employee Earnings, Benefits and Trade Union Membership, Australia, August 2012. Cat. no. 6310.0. Canberra: ABS.

Australian Bureau of Statistics (ABS) (2014a) Australian System of National Accounts, 2013-14. Time series spreadsheets, Table 1. 'Key National Accounts Aggregates'. Cat. no. 5204.0. Canberra: ABS.

Australian Bureau of Statistics (ABS) (2014b) Average Weekly Earnings, Australia, May 2014. Data cubes, Table 15. 'Average Weekly Cash Earnings, Australia by Sector (Dollars) - Original’. Cat. no. 6302.0. Canberra: ABS.

Australian Bureau of Statistics (ABS) (2014c) Consumer Price Index, Australia, September 2014. Time series spreadsheets, Tables 1 and 2. 'CPI: All Groups, Index Numbers and Percentage Changes’. Cat. no. 6401.0. Canberra: ABS.

Australian Bureau of Statistics (ABS) (2014d) Employee Earnings, Benefits and Trade Union Membership, Australia, August 2013. Cat. no. 6310.0. Canberra: ABS.

Australian Bureau of Statistics (ABS) (2014e) Employee Earnings, Benefits and Trade Union Membership, Australia, August 2013. Time series spreadsheets, Table 4. 'Employees in main job, Mean weekly earnings in main job, by fulltime or part-time status in main job, by age group (years), by sex, 1990-2013'. Cat. no. 6310.0. Canberra: ABS.

Australian Bureau of Statistics (ABS) (2014f) Job Vacancies, Australia, August 2014. Time series spreadsheets, Table 1. 'Job Vacancies, States and Territories'. Cat. no. 6354.0. Canberra: ABS.

Australian Bureau of Statistics (ABS) (2014g) Job Vacancies, Australia, August 2014. Time series spreadsheets, Table 2. 'Job Vacancies, Private Sector, States and Territories’. Cat. no. 6354.0. Canberra: ABS. 
Australian Bureau of Statistics (ABS) (2014h) Labour Force, Australia, Detailed, Quarterly, August 2014. Data cubes, E04. 'Employed persons by Actual hours worked, State and Territory, Sex and Status in employment, November 1984 onwards'. Cat. no. 6291.0.55.003. Canberra: ABS.

Australian Bureau of Statistics (ABS) (2014i) Labour Force, Australia, Detailed, Quarterly, August 2014. Data cubes, E05. 'Employed persons by Industry (ANZSIC sub-division), Sex, Age and Status in employment, August 1991 onwards'. Cat. no. 6291.0.55.003. Canberra: ABS.

Australian Bureau of Statistics (ABS) (2014j) Labour Force, Australia, Detailed Electronic Delivery, October 2014. Data cubes, UM3. 'Unemployed Persons by State and Territory, Age, Sex and Duration of Job Search, April 2001 onwards’. Cat. no. 6291.0.55.001. Canberra: ABS.

Australian Bureau of Statistics (ABS) (2014k) Labour Force, Australia, Detailed Electronic Delivery, October 2014. Time series spreadsheets, Table 1. 'Labour Force Status by Social Marital Status, Age and Sex’. Cat. no. 6291.0.55.001. Canberra: ABS.

Australian Bureau of Statistics (ABS) (2014l) Labour Force, Australia, October 2014. Time series spreadsheets, Table 18. 'Labour force status by Sex - Persons aged 15 to 64 years - Trend, Seasonally adjusted and Original’. Cat. no. 6202.0. Canberra: ABS.

Australian Bureau of Statistics (ABS) (2014m) Labour Force, Australia, October 2014. Time series spreadsheets, Table 22. 'Labour underutilisation by Age and Sex - Trend, Seasonally adjusted and Original’. Cat. no. 6202.0. Canberra: ABS.

Australian Bureau of Statistics (ABS) (2014n) Wage Price Index, Australia, September 2014. Time series spreadsheets, Table 9b. 'Ordinary Hourly Rates of Pay Excluding Bonuses: Sector by Industry, Original (Quarterly Index Numbers)'. Cat. no. 6345.0. Canberra: ABS.

Australian Government (2014a) Budget 2014-15: Stronger participation incentives for job seekers under 30. Canberra: Department of Human Services. Available at: humanservices.gov.au/corporate/publications-andresources/budget/1415/measures/job-seekers/64-90066 (accessed 12 January 2015).

Australian Government (2014b) Employment Services 2015: Fact Sheet - October 2014. Canberra: Department of Employment. Available at: employment.gov.au/employment-services-2015 (accessed 12 January 2015).

Australian Government (2014c) Skill Shortages, Australia, 2013-14. Canberra: Department of Employment.

Australian Government (2014d) Trends in Federal Enterprise Bargaining, June Quarter 2014. Historical table: All wage agreements, by ANZSIC division, current on the last day of the quarter: December quarter 1991 - June quarter 2014. Canberra: Department of Employment.

Australian Government (2014e) Vacancy Report, October 2014. Canberra: Department of Employment. 
Fair Work Australia (FWA) (2010) Decision: Annual Wage Review 2009-10 ([2010] FWAFB 4000). Melbourne: FWA.

Fair Work Australia (FWA) (2011) Decision: Annual Wage Review 2010-11 ([2011] FWAFB 3400). Melbourne: FWA.

Fair Work Australia (FWA) (2012) Decision: Annual Wage Review 2011-12 ([2012] FWAFB 5000). Melbourne: FWA.

Fair Work Commission (FWC) (2013) Decision: Annual Wage Review 2012-13 ([2013] FWCFB 4000). Melbourne: FWC.

Fair Work Commission (FWC) (2014) Decision: Annual Wage Review 2013-14 ([2014] FWCFB 3500). Melbourne: FWC.

Graduate Careers Australia (GCA) (2014) GradStats: Employment and Salary Outcomes of Recent Higher Education Graduates - Survey Highlights. Melbourne: GCA.

Gregory, R. (2012) Dark corners in a bright economy: The lack of jobs for unskilled men. Australian Bulletin of Labour 38(1): 2-25.

Gong, X. (2011) The added worker effect for married women in Australia. Economic Record 87(278): 414-426.

Healy, J. (2011) The quest for fairness in Australian minimum wages. Journal of Industrial Relations 53(5): 662-680.

Healy, J. (2014) The Australian labour market in 2013. Journal of Industrial Relations 56(3): 345-364.

Janda, M. (2014) GDP data show Australia in income recession; falling dollar a 'silver lining'. ABC News online. Available at: http://ab.co/1ymQAAh (accessed 4 December 2014)

Karmel, T. and Oliver, D. (2011) Effect of the downturn on apprentices and trainees. National Centre for Vocational Education Research, Adelaide.

National Centre for Vocational Education Research (NCVER) (2014) Australian vocational education and training statistics: Historical time series of apprenticeships and traineeships in Australia from 1963. NCVER, Adelaide.

Organisation for Economic Co-operation and Development (OECD) (2014a) OECD.StatExtracts, 'Incidence of unemployment by duration'. Available at: stats.oecd.org/Index.aspx?DataSetCode=DUR_D (accessed 26 November 2014).

Organisation for Economic Co-operation and Development (OECD) (2014b) OECD.StatExtracts, 'FTPT employment based on a common definition'. Available at: stats.oecd.org/Index.aspx?DataSetCode=FTPTC D (accessed 26 November 2014).

Organisation for Economic Co-operation and Development (OECD) (2014c) OECD.StatExtracts, 'Incidence of involuntary part time workers'. Available at: stats.oecd.org/Index.aspx?DataSetCode=INVPT_I (accessed 26 November 2014). 
Organisation for Economic Co-operation and Development (OECD) (2014d)

OECD.StatExtracts, 'Labour force statistics by sex and age'. Available at: stats.oecd.org/Index.aspx?DataSetCode=LFS_D (accessed 26 November 2014).

Organisation for Economic Co-operation and Development (OECD) (2014e)

OECD.StatExtracts, 'Minimum relative to average wages of full-time workers'. Available at: stats.oecd.org/Index.aspx?DataSetCode=MIN2AVE (accessed 26 November 2014).

Organisation for Economic Co-operation and Development (OECD) (2014f)

OECD.StatExtracts, 'Growth in GDP per capita, productivity and unit labour costs'. Available at: stats.oecd.org/Index.aspx?DataSetCode=PDB_GR (accessed 26 November 2014).

Reserve Bank of Australia (RBA) (2014) Statement on Monetary Policy, August 2014. Available at: rba.gov.au/publications/smp/2014/aug/html/index.html (accessed 12 January 2015).

Richardson, S. (2007) What is a skill shortage? National Centre for Vocational Education Research, Adelaide.

The Conversation (2014a) Employment policy and job creation: Some practical solutions. Available at: theconversation.com/employment-policy-and-jobcreation-some-practical-solutions-29893 (accessed 11 January 2015).

The Conversation (2014b) Toyota names 2017 end, Australian car making to cease: Experts react. Available at: theconversation.com/toyota-names-2017-endaustralian-car-making-to-cease-experts-react-23037 (accessed 11 January 2015).

Wilkins, R. and Wooden, M. (2014) Two decades of change: the Australian labour market, 1993-2013. Australian Economic Review 47(4): 417-431. 
TABLE 1 - MACROECONOMIC CONDITIONS, AUSTRALIA AND THE OECD, 2011-2014

\begin{tabular}{lcccc}
\hline Annual percentage change (\%) & 2011 & 2012 & 2013 & 2014 \\
\hline Australia & & & & \\
Gross Domestic Product (GDP) & 2.3 & 3.7 & 2.5 & 2.5 \\
GDP per capita & 0.9 & 2.1 & 0.7 & 0.8 \\
GDP per hour worked & -0.4 & 2.3 & 3.4 & 1.4 \\
OECD & & & & \\
GDP & 3.0 & 1.9 & 1.5 & 1.3 \\
GDP per capita & 2.3 & 1.3 & 0.9 & 0.8 \\
GDP per hour worked & 1.5 & 1.1 & 0.5 & 0.8 \\
\hline
\end{tabular}

Sources: ABS (2014a); OECD (2014f).

Notes: (1) Figures are for financial years, ending in the year shown. (2) GDP figures are adjusted for underlying price changes. (3) OECD figures are for the 34 OECD member countries. 
TABLE 2 - LABOUR FORCE PARTICIPATION, EMPLOYMENT, AND UNEMPLOYMENT RATES, PERSONS AGED 15-64 YEARS, BY SEX, 2012-2014

\begin{tabular}{lrrrrrr}
\hline Percentage (\%) & \multicolumn{3}{c}{ Males } & \multicolumn{5}{c}{ Females } \\
\hline & $\mathbf{2 0 1 2}$ & $\mathbf{2 0 1 3}$ & $\mathbf{2 0 1 4}$ & $\mathbf{2 0 1 2}$ & $\mathbf{2 0 1 3}$ & $\mathbf{2 0 1 4}$ \\
Australia & & & & & & \\
$\quad$ Participation rate & 82.5 & 82.5 & 82.1 & 70.4 & 70.5 & 70.5 \\
Employment/Population ratio & 78.2 & 77.7 & 77.1 & 66.6 & 66.5 & 66.1 \\
FT Employment/Population ratio & 66.4 & 65.8 & 64.9 & 36.7 & 36.4 & 36.1 \\
Unemployment rate & 5.2 & 5.8 & 6.1 & 5.4 & 5.7 & 6.2 \\
OECD & & & & & & \\
Participation rate & 79.7 & 79.7 & -- & 62.3 & 62.6 & -- \\
Employment/Population ratio & 73.2 & 73.2 & -- & 57.2 & 57.5 & - \\
FT Employment/Population ratio & 63.4 & 64.2 & -- & 40.4 & 41.4 & - \\
$\quad$ Unemployment rate & 8.1 & 8.1 & -- & 8.2 & 8.1 & - \\
\hline Sources: ABS (2014l); OECD (2014b, 2014d). & & & & & &
\end{tabular}

Notes: (1) Australian figures are averages of original estimates for 12 months to October of each year. (2) OECD figures are for calendar years; OECD 2014 figures were not available at time of writing. (3) 'Full-time' is 35 or more hours per week for Australia, but 30 or more hours per week for the OECD. 
TABLE 3 - LABOUR FORCE UNDERUTILISATION RATES, BY SEX AND AGE, 2012-2014

\begin{tabular}{lrrrrrr}
\hline Percentage (\%) & \multicolumn{3}{c}{ Males } & \multicolumn{4}{c}{ Females } \\
\hline & 2012 & 2013 & 2014 & 2012 & 2013 & 2014
\end{tabular}

\section{Australia}

Unemployment rate

All 15 years and over

15-24 years

$\begin{array}{llllll}5.1 & 5.6 & 5.9 & 5.3 & 5.6 & 6.1\end{array}$

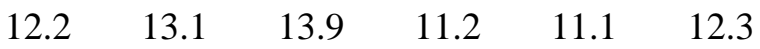

Long-term unemployment rate

All 15 years and over

$\begin{array}{llllll}19.8 & 19.4 & 22.8 & 17.4 & 18.2 & 20.4\end{array}$

$15-24$ years

$\begin{array}{llllll}14.8 & 14.5 & 20.2 & 10.6 & 13.0 & 15.1\end{array}$

Underemployment rate

All 15 years and over

$\begin{array}{lrrrrr}5.4 & 5.6 & 6.0 & 9.4 & 9.5 & 10.0\end{array}$

15-24 years

$\begin{array}{llllll}11.7 & 11.8 & 13.6 & 15.9 & 16.4 & 17.9\end{array}$

\section{OECD}

Unemployment rate

All 15 years and over

15-24 years

$\begin{array}{rrrrrr}7.9 & 7.9 & -- & 8.0 & 7.9 & -- \\ 16.8 & 16.6 & -- & 15.7 & 15.6\end{array}$

Long-term unemployment rate

All 15 years and over

$\begin{array}{llllll}34.3 & 35.3 & -- & 34.1 & 35.2 & --\end{array}$

15-24 years

$\begin{array}{llllll}23.3 & 23.8 & -- & 21.1 & 21.1 & --\end{array}$

Involuntary part-time employment rate

\begin{tabular}{lllllll} 
All 15 years and over & 1.9 & 1.6 & -- & 4.6 & 3.9 & - \\
$15-24$ years & 3.8 & 3.5 & -- & 6.1 & 5.5 & -- \\
\hline
\end{tabular}

Sources: ABS (2014k, 2014j, 2014m); OECD (2014a, 2014c, 2014d).

Notes: (1) Unemployment and underemployment rates are expressed as proportions of the labour force, while long-term unemployment rates are expressed as proportions of total unemployment. (2) Longterm unemployment is defined as one year or more. (3) All Australian data are original series. (4) Australian unemployment and long-term unemployment rates are averages of the 12 months to October of each year; underemployment rates are averages of the four quarters to August. (5) OECD figures are averaged over the months/quarters of each calendar year; OECD 2014 figures were not available at time of writing. (6) Involuntary part-time employment refers to persons working less than 30 hours per week who prefer to work 30 or more hours. 


\begin{tabular}{lrrr}
\hline & 2012 & 2013 & 2014 \\
\hline Number of vacancies ('000) & 173.5 & 139.8 & 147.2 \\
Total (ABS) & 160.0 & 129.0 & 134.6 \\
Private sector (ABS) & 159.5 & 139.7 & 155.6 \\
Internet Vacancy Index - Total & 64.3 & 53.4 & 60.1 \\
Internet Vacancy Index - Skilled occupations & & & \\
Change from same period in previous year (\%) & -5.4 & -19.4 & 5.3 \\
Total (ABS) & -3.6 & -19.4 & 4.3 \\
Private sector (ABS) & -19.0 & -12.4 & 11.4 \\
Internet Vacancy Index - Total & -19.9 & -16.9 & 12.5 \\
Internet Vacancy Index - Skilled occupations & & & \\
Proportion of vacancies filled (\%) & 65 & 70 & 73 \\
All occupations assessed & 73 & 76 & 81 \\
Professions & 61 & 66 & 69 \\
Technicians and Trades & & & \\
Number of suitable applicants per vacancy (\%) & 1.9 & 2.3 & 2.2 \\
All occupations assessed & 2.2 & 2.9 & 3.0 \\
Professions & 1.7 & 2.1 & 1.6 \\
Technicians and Trades & & & \\
\hline Sources: ABS (2014f, 2014g); Australian Government (2014c, 2014e). & & & \\
\hline
\end{tabular}

Notes: (1) ABS estimates of job vacancies are from a telephone survey of employers. The data are trend estimates for the August quarter of each year. (2) Internet Vacancy Index (IVI) data are counts of new online job advertisements lodged on major recruitment websites. The data are trend estimates for the month of October each year. (3) Skilled occupations in IVI are professional and technical/trades. 
TABLE 5 - CHANGES IN COMPOSITION OF THE AUSTRALIAN EMPLOYEE WORKFORCE, BY SELECTED CHARACTERISTICS, 2012-2014

\begin{tabular}{|c|c|c|c|c|c|c|}
\hline \multirow[t]{2}{*}{$\begin{array}{l}\text { Percentage change on same } \\
\text { quarter of previous year (\%) }\end{array}$} & \multicolumn{3}{|c|}{ Change in employment } & \multicolumn{3}{|c|}{ Change in hours worked } \\
\hline & 2012 & 2013 & 2014 & 2012 & 2013 & 2014 \\
\hline Overall & 1.9 & 1.8 & 1.2 & 2.3 & 1.4 & 0.6 \\
\hline \multicolumn{7}{|l|}{ Sex } \\
\hline Male & 2.0 & 1.6 & 0.9 & 2.5 & 1.2 & 0.4 \\
\hline Female & 1.7 & 2.0 & 1.5 & 2.0 & 1.8 & 0.9 \\
\hline \multicolumn{7}{|l|}{ Age } \\
\hline 15-24 years & -0.6 & -0.6 & -1.2 & -0.7 & -2.3 & -3.0 \\
\hline 25-54 years & 1.8 & 2.1 & 1.3 & 2.2 & 1.9 & 1.0 \\
\hline 55 years and over & 5.0 & 3.1 & 3.0 & 5.3 & 2.8 & 2.0 \\
\hline \multicolumn{7}{|l|}{ Working hours } \\
\hline 1-15 per week & -0.1 & 2.5 & 5.6 & 0.3 & 1.7 & 5.0 \\
\hline 16-34 per week & 0.2 & 1.1 & 2.1 & 0.2 & 0.9 & 2.2 \\
\hline 35-49 per week & 2.1 & 1.6 & 1.4 & 2.0 & 1.5 & 1.3 \\
\hline 50 or more per week & 4.4 & 1.4 & -2.3 & 4.5 & 1.5 & -2.3 \\
\hline \multicolumn{7}{|l|}{ States and Territories } \\
\hline New South Wales & 1.3 & 2.5 & 0.8 & 1.5 & 2.2 & 0.3 \\
\hline Victoria & 0.6 & 1.5 & 0.4 & 0.2 & 0.9 & -0.3 \\
\hline Queensland & 2.1 & 0.5 & 2.7 & 3.4 & 1.0 & 1.3 \\
\hline South Australia & 0.4 & 1.9 & -1.4 & -0.7 & 2.0 & -1.4 \\
\hline Western Australia & 7.2 & 3.4 & 2.4 & 9.5 & 1.9 & 2.3 \\
\hline Tasmania & -0.8 & -0.4 & 1.0 & -1.3 & -2.2 & 3.5 \\
\hline Northern Territory & 3.1 & 2.0 & 6.5 & 3.9 & 0.3 & 7.4 \\
\hline Australian Capital Territory & 1.8 & 0.8 & 0.6 & 2.6 & -0.2 & -1.3 \\
\hline
\end{tabular}

Sources: ABS (2014h, 2014i).

Notes: (1) All figures are based on original-series estimates for employees. (2) Changes are calculated by comparing average employment in the four quarters to August of each year with the average of the four preceding quarters. 
FIGURE 1 - FULL-TIME MEAN AND MEDIAN EARNINGS GROWTH, BY SEX, 2004-2013

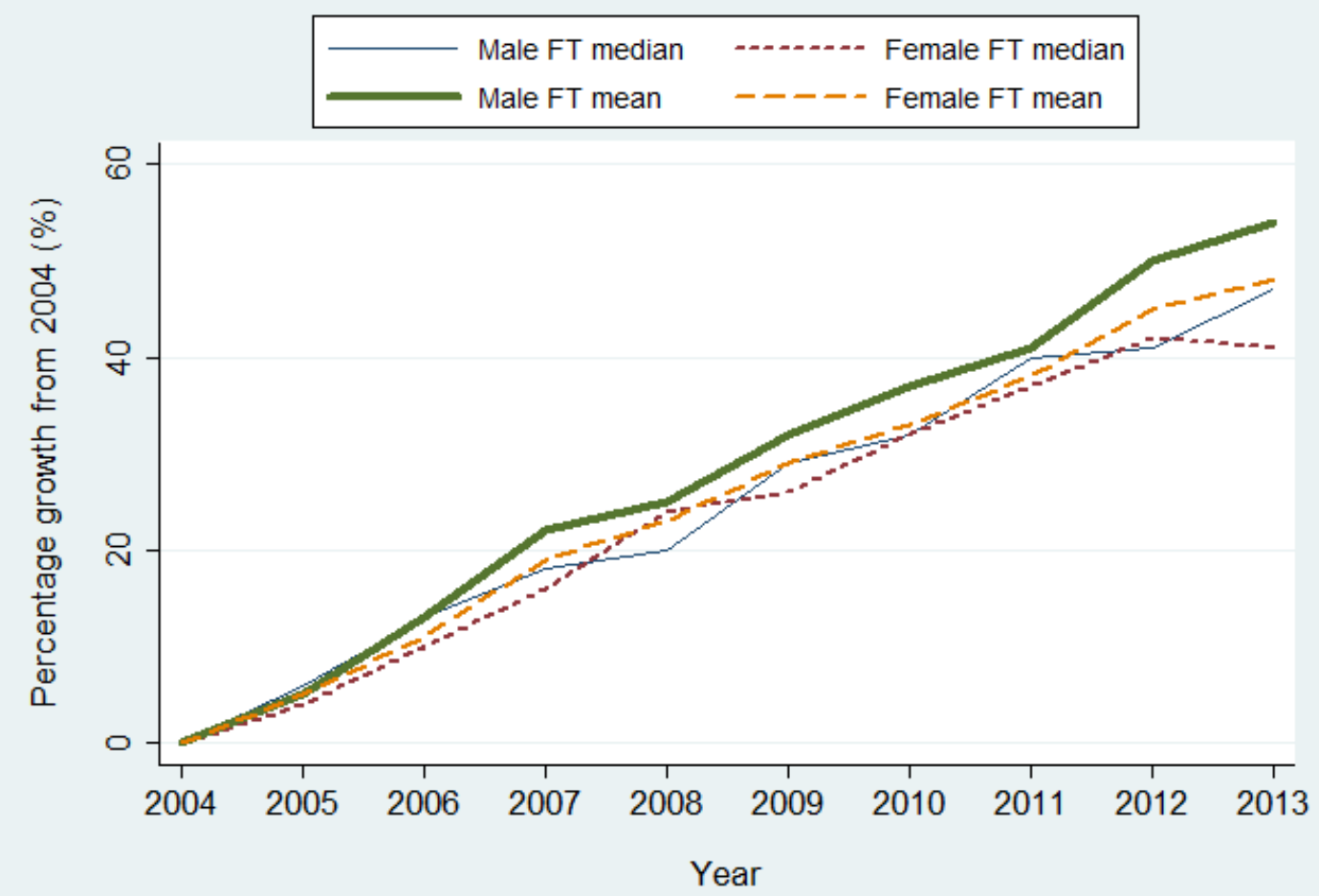

Sources: ABS (2005, 2006, 2007, 2008, 2009, 2010, 2011, 2012, 2013, 2014d, 2014e).

Note: Figures are for full-time employees in their main job and refer to the month of August each year. 
TABle 6 - VAlue of The National Minimum WAGe, 2011-2014

\begin{tabular}{lrrrr}
\hline & 2011 & 2012 & 2013 & 2014 \\
\hline National Minimum Wage (NMW) (\$ per week) & 589.30 & 606.40 & 622.20 & 640.90 \\
NMW change on previous year (\%) & 3.4 & 2.9 & 2.6 & 3.0 \\
CPI change on previous year (\%) & 3.5 & 1.2 & 2.4 & 3.0 \\
AWCE change on previous year (\%) & 4.3 & 3.2 & 4.5 & 2.6
\end{tabular}

WPI change on previous year (\%)

$\begin{array}{lllll}\text { All industries } & 3.8 & 3.7 & 2.9 & 2.6 \\ \text { Accommodation and Food Services } & 3.0 & 3.3 & 2.6 & 2.2 \\ \text { Retail Trade } & 3.3 & 2.7 & 2.7 & 2.4\end{array}$

NMW \% of Average Weekly Cash Earnings in Australia

$\begin{array}{lllll}\text { Full-time, Adult, Ordinary-time - Males } & 40.6 & 40.6 & 40.0 & 39.9 \\ \text { Full-time, Adult, Ordinary-time - Females } & 48.9 & 48.7 & 47.8 & 48.2 \\ \text { Full-time, Adult, Ordinary-time - Persons } & 43.4 & 43.3 & 42.5 & 42.7\end{array}$

\section{MW \% of Median Full-time Earnings in selected OECD countries}

\begin{tabular}{lllll} 
Australia & 53.6 & 52.7 & 54.0 & - \\
New Zealand & 58.8 & 59.9 & 59.5 & - \\
United Kingdom & 46.7 & 47.2 & 46.9 & - \\
United States & 38.3 & 37.8 & 37.4 & - \\
\hline
\end{tabular}

Sources: ABS (2014b, 2014c, 2014n); FWA (2010, 2011, 2012); FWC (2013, 2014); OECD (2014e).

Notes: (1) NMW rates take effect on 1 July each year. (2) CPI data are for the June quarter of each year and show the change in 'All groups CPI' from the same quarter of the previous year. (3) WPI data are for the June quarter of each year and show the change in 'Ordinary-time hourly rates of pay, excluding bonuses' from the same quarter of the previous year. (4) AWCE data are for May of each year and show full-time, adult ordinary-time weekly earnings. (5) OECD 2014 data were not available at time of writing. 


\section{Endnotes}

${ }^{1}$ These revisions account for the difference between the GDP per hour worked results in Table 1 of the current article and Table 1 of Healy (2014). GDP per hour worked was revised upwards from $2.0 \%$ to $2.3 \%$ for 2012 , and from $2.2 \%$ to $3.4 \%$ for 2013 . The revisions resulted from 'rebenchmarking' the data on hours worked to reflect the updated population figures from the 2011 Census.

${ }^{2}$ These two measures are different, as part-time workers can seek additional hours without necessarily wanting to work full-time.

${ }^{3}$ In the period from 1993 to 2013, Manufacturing's share of total employment in Australia shrank from 13.6\% to $8.1 \%$ (Wilkins and Wooden, 2014).

${ }^{4}$ Hourly wage data, which would allow the inclusion of part-time employees, are not readily available.

${ }^{5}$ The median is the mid-point of the distribution and - unlike the mean - is not affected by a change in the overall spread (dispersion) of values.

${ }^{6}$ Other evidence of slowing wage growth is available from the Australian Government's database of wage settlements in Federal enterprise bargaining agreements. For all agreements that were current on 30 June 2014, and for which wage settlements were quantifiable, the average annualised wage increase per employee (AAWI) was 3.5\%. This is the lowest percentage increase recorded since June 2000. The AAWI figure has fallen steadily for each of the past five years, from 4.0\% in June 2009 (Australian Government, 2014d). 


\section{University Library}

\section{- M M I E R R V A gateway to Melbourne's research publications}

Minerva Access is the Institutional Repository of The University of Melbourne

Author/s:

Healy, J

Title:

The Australian labour market in 2014: Still ill?

Date:

2015-06-01

Citation:

Healy, J. (2015). The Australian labour market in 2014: Still ill?. JOURNAL OF INDUSTRIAL RELATIONS, 57 (3), pp.348-365. https://doi.org/10.1177/0022185615571981.

Persistent Link:

http://hdl.handle.net/11343/113746 